\title{
On-farm Evaluation of Balanced Fertilization in Rice-groundnut Cropping System for Productivity, Nutrient Use Efficiency and Profitability
}

T.R. Mohanty, R.K. Paikray, A.K. Patra, S.K. Swain, K.C. Sahoo, P.K. Samant ${ }^{1}$

$10.18805 / L R-4789$

\begin{abstract}
Background: Increasing cost of fertilizers warrants the necessity of finding methods for increasing the use efficiency of nitrogen in a cropping system. Data from on-farm research on evaluation of use efficiency of applied nutrients using check plot or omission plot technique has been lacking.

Methods: A researcher designed and farmer managed experiment was conducted in Angul district under Mid Central Table Land Zone of Odisha to study the on-farm crop response to plant nutrients by involving 12 farmers during 2015-16 and another 12 farmers during 2016-17 in rice (Oryza sativa L.)- groundnut (Arachis hypogaea L.) cropping system with seven treatments, viz. control (no fertilizer application), recommended $\mathrm{N}$ alone (N-0-0-0), NP (N-P-0-0), NK (N-0-K-0), NPK (N-P-K-0), NPK+ZnSO $/ \mathrm{CaSO}_{4}(\mathrm{~N}-\mathrm{P}-\mathrm{K}-$ $\mathrm{ZnSO}_{4}$ in rice and N-P-K- $\mathrm{CaSO}_{4}$ in groundnut) and farmers' practice (FP).

Result: The highest system rice equivalent yield (REY) (12.63 t/ha) was recorded with the recommended doses of nitrogen, phosphorus and potassium (N-P-K @ 80, 17.5 and $33 \mathrm{~kg} / \mathrm{ha})+25 \mathrm{~kg} \mathrm{ZnSO} / \mathrm{ha}$ to rice and recommended doses of nitrogen, phosphorus and potassium (N-P-K@ $@ 40,17.5$ and $33 \mathrm{~kg} / \mathrm{ha}$ ) $+250 \mathrm{~kg} \mathrm{CaSO} / \mathrm{ha}$ to groundnut followed by recommended NPK alone to both the crops without $\mathrm{ZnSO}_{4} / \mathrm{CaSO}_{4}(12.18 \mathrm{t} / \mathrm{ha}$ ). Partial factor productivity (PFP) of $\mathrm{N}$ in rice-groundnut system can be increased to $42 \%$ over sole $\mathrm{N}$ application through application of recommended quantity of NPK. The agronomic efficiency (AE) of N increased by 122,87 and $186 \%$ in rice groundnut cropping system by applying recommended doses of $\mathrm{N}$ with $\mathrm{P}, \mathrm{K}$ and $\mathrm{PK}$ over $\mathrm{N}$ alone, respectively. Application of recommended quantity of $\mathrm{NPK}+\mathrm{ZnSO}_{4}$ to rice and $\mathrm{NPK}+\mathrm{CaSO}_{4}$ to succeeding groundnut crop recorded highest system net return of Rs.92690/ha followed by application of recommended NPK only to both the crops (Rs.89950/ha). Application of balanced fertilizer improved the status of organic carbon and available $\mathrm{N}, \mathrm{P}$ and $\mathrm{K}$ at the end of the cropping season in both the years compared to control.
\end{abstract}

Key words: Agronomic efficiency, Balanced fertilization, Partial factor productivity, Rice-groundnut system.

\section{INTRODUICTION}

Rice-groundnut is the predominant cropping system in Mid Central Table Land Zone of Odisha covering about 10,830 ha (Govt. of Odisha, 2015). However, the productivity of both rice and groundnut in Odisha are lower than national productivity and it might be due to low and imbalanced applications of nutrients.

Cereal production in the country increased by five fold, while fertilizer consumption increased 322 times during the period from 1950-51 to 2007-08, implying a very low fertilizer use efficiency (Rajendra Prasad, 2009). Nitrogen, phosphorus and potassium are the macro-nutrients required by the cereal-based systems for balanced nutrition. Among the micronutrients, Zn significantly influences crop growth and yield (Panwar et al., 2019). Generally, most of the Indian soils are deficient in $S$ and Zn (Singh et al., 2008). Sufficient on-farm data regarding use efficiency of applied nutrients using check plot or omission plot technique has been lacking.

Considering the above facts, a participatory research was carried out in farmers' fields to evaluate the production potential, profitability and nutrient use efficiency of applied nutrients under balanced fertilization in rice-groundnut cropping system.
Department of Agronomy, Directorate of Research, Odisha University of Agriculture and Technology, Bubaneswar-751 003, Odisha, India.

1Department of Soil Science, Directorate of Research, Odisha University of Agriculture and Technology, Bubaneswar-751 003, Odisha, India.

Corresponding Author: T.R. Mohanty, Department of Agronomy, Directorate of Research, Odisha University of Agriculture and Technology, Bubaneswar-751 003, Odisha, India.

Email: tusharranjan70@gmail.com

How to cite this article: Mohanty, T.R., Paikray, R.K., Patra, A.K., Swain, S.K., Sahoo, K.C. and Samant, P.K. (2022). On-farm Evaluation of Balanced Fertilization in Rice-groundnut Cropping System for Productivity, Nutrient Use Efficiency and Profitability. Legume Research. DOI: 10.18805/LR-4789.

Submitted: 11-09-2021 Accepted: 29-12-2021 Online: 19-02-2022

\section{MATERIALS AND METHODS}

Field experiments were conducted in 24 nos. of farmers' fields at three locations (Koshala, Machakutta and Handiguda villages) of Chhendipada block in Angul district of Odisha during 2015-16 and 2016-17. The villages were adopted by All India Coordinated Research Project on 
Integrated Farming Systems, Orissa University of Agriculture and Technology, Bhubaneswar. Four farmers were selected from each village to conduct the experiment during each year. A set of seven fertilizer treatments were allotted to seven fixed plots (100 $\mathrm{m}^{2}$ each) in a single block in each of the farmers' field both in rice and groundnut. The seven treatments were Control (no fertilizer application), recommended $\mathrm{N}$ alone (N-0-0-0), NP (N-P-0-0), NK (N-0$\mathrm{K}-0), \mathrm{NPK}(\mathrm{N}-\mathrm{P}-\mathrm{K}-0), \mathrm{NPK}+\mathrm{ZnSO}_{4} / \mathrm{CaSO}_{4}\left(\mathrm{~N}-\mathrm{P}-\mathrm{K}-\mathrm{ZnSO}_{4}\right.$ in rice and $\mathrm{N}-\mathrm{P}-\mathrm{K}-\mathrm{CaSO}_{4}$ in groundnut) and Farmers' practice (FP). The recommended doses of $\mathrm{N}, \mathrm{P}$ and $\mathrm{K}$ (elemental form) were $80,17.5$ and $33 \mathrm{~kg} / \mathrm{ha}$ for rice and $20,17.5$ and $33 \mathrm{~kg} / \mathrm{ha}$ for groundnut, respectively. The recommended quantity of $\mathrm{ZnSO}_{4}$ and $\mathrm{CaSO}_{4}$ were $25 \mathrm{~kg} / \mathrm{ha}$ and $250 \mathrm{~kg} / \mathrm{ha}$ for rice and groundnut, respectively. In FP, rice crop received $61,13.3$ and $26 \mathrm{~kg}$ of $\mathrm{N}, \mathrm{P}$ and $\mathrm{K} / \mathrm{ha}$, respectively, whereas groundnut crop received $14,14.9$ and $24.8 \mathrm{~kg}$ of $\mathrm{N}, \mathrm{P}$ and $\mathrm{K} / \mathrm{ha}$, respectively. Nitrogen, $\mathrm{P}, \mathrm{K}, \mathrm{Zn}$ and $\mathrm{S}$ were applied through urea [CO $\left(\mathrm{NH}_{2}\right)_{2}$ ] containing $46 \% \mathrm{~N}$, Single superphosphate $\left[\mathrm{Ca}\left(\mathrm{H}_{2} \mathrm{PO}_{4}\right)_{2}\right.$ ] containing $16 \% \mathrm{P}_{2} \mathrm{O}_{5}$, potassium chloride $\left[\mathrm{KCL}\right.$ ] containing $60 \% \mathrm{~K}_{2} \mathrm{O}$, zinc sulphate $\left[\mathrm{ZnSO}_{4} \cdot 7 \mathrm{H}_{2} \mathrm{O}\right]$ containing $21 \% \mathrm{Zn}$ and calcium sulphate $\left[\mathrm{CaSO}_{4} .2 \mathrm{H}_{2} \mathrm{O}\right.$ ] containing $18.5 \% \mathrm{~S}$, respectively. In rice, the total quantity of recommended $\mathrm{P}, \mathrm{K}$ and $\mathrm{ZnSO}_{4}$ were applied as basal while $\mathrm{N}$ was applied in three splits i.e. $25 \%$ as basal, $50 \%$ at the time of tillering and rest $25 \%$ at P.I. stage. Moreover, in groundnut, the total quantity of recommended $\mathrm{N}, \mathrm{P}, \mathrm{K}$ and $\mathrm{CaSO}_{4}$ were applied as basal. The treatments were applied to rice and groundnut crops in sequence. Rice cultivar 'Naveen' and groundnut cultivar 'Kadiri 6' was taken for the experiment. In 2015-16, rice crop received $791.7 \mathrm{~mm}$ rainfall in 47 rainy days and groundnut received $94.1 \mathrm{~mm}$ rainfall in six rainy days. Similarly, in 2016-17, rice crop received $914.6 \mathrm{~mm}$ rainfall in 45 rainy days and groundnut received $52 \mathrm{~mm}$ rainfall in five rainy days.

The experiment was conducted in randomized block design taking each farmer as a replication.Soil samples were collected from each of the 24 locations at the start and end of cropping cycle for both the years from a depth of $0-15 \mathrm{~cm}$ and analysed for organic carbon, N, P and $\mathrm{K}$ using standard procedures (Jackson, 1973). The details of initial physicochemical properties of soil are given in Table 1. Plant samples were also analyzed for $\mathrm{N}, \mathrm{P}$ and $\mathrm{K}$ concentration in grain and straw.

Nutrient use efficiencies (NUE) were estimated in terms of partial factor productivity (PFP) and agronomic efficiency
(AE). Partial factor productivity, calculated as the ratio of the grain yield to applied nutrient, can be increased by increasing the amount, uptake and utilization of indigenous nutrients and by increasing the uptake and utilization efficiency of applied nutrients for grain production (Cassman et al. 1996). The agronomic efficiency (AE) is the ratio of incremental increase in grain yield per unit of nutrient applied over control. It quantifies the direct impact of an added nutrient on economic yield enhancement. The PFP (kg grain/ $\mathrm{kg}$ of native + applied nutrient) and $\mathrm{AE}$ (kg grain $/ \mathrm{kg}$ nutrient applied) for applied N, P and $\mathrm{K}$ were calculated using the following equations.

$\mathrm{PFPn}=\mathrm{Yn} / \mathrm{Fn}, \mathrm{Ynp} / \mathrm{Fn}, \mathrm{Ynk} / \mathrm{Fn}$ and $\mathrm{Ynpk} / F n$

$P F P p=Y n p / F p$ and $Y n p k / F p$

$P F P k=Y n k / F k$ and $Y n p k / F k$

$A E n=\left(Y n-Y_{0}\right) / F n,\left(Y n p-Y_{0}\right) / F n,\left(Y n k-Y_{0}\right) / F n$ and $\left(Y n p k-Y_{0}\right) / F n$

$A E p=\left(Y n p-Y_{0}\right) / F p$ and $\left(Y n p k-Y_{0}\right) / F p$

$A E k=\left(Y n k-Y_{0}\right) / F k$ and $\left(Y n p k-Y_{0}\right) / F k$

Where

PFPn, PFPp and PFPk are the partial factor productivity of $\mathrm{N}, \mathrm{P}$ and $\mathrm{K}$, respectively, $Y_{0}, \mathrm{Yn}, \mathrm{Ynp}, \mathrm{Ynk}$ and $Y n p k$ are the yield of respective treatments (control, $N$ alone, $N$ with $P, N$ with $\mathrm{K}$ and $\mathrm{N}$ with $\mathrm{PK}$ ) and $\mathrm{Fn}, \mathrm{Fp}$ and $\mathrm{Fk}$ are the amounts of applied $\mathrm{N}, \mathrm{P}$ and $\mathrm{K}$, respectively. The quantity of nutrient inputs and economic outputs are expressed in $\mathrm{kg} / \mathrm{ha}$. Uptake of $\mathrm{N}, \mathrm{P}$ and $\mathrm{K}$ were computed by multiplying the respective nutrient concentrations with yield.

Gross returns, net returns, B:C ratio (gross return per rupee invested) and rice-groundnut system productivity was evaluated using the minimum support price for economic products declared by Government of India and prevailing market prices for by-products during the year. Statistical analyses were done using standard methodology for randomized block design.

\section{RESULTS AND DISCUSSION}

\section{Crop and system yields}

Fertilizer application significantly influenced the yield of rice, groundnut and of the system (Table 2). The mean yield advantages in rice grain due to application of recommended quantity of N, NP, NK and NPK over control were to the tune of $35,60,58$ and $82 \%$, respectively. Similarly, the increases in pod yield of groundnut due to application of N, NP, NK and NPK were $21,68,48$ and $84 \%$ over control, respectively. However, the highest grain yield of rice (5.06 t/ha) and pod

Table 1: Initial Physico-chemical properties of soil (data collected from 12 sites each year).

\begin{tabular}{|c|c|c|c|c|c|c|}
\hline \multirow{2}{*}{ Treatment } & \multicolumn{3}{|c|}{$2015-16$} & \multicolumn{3}{|c|}{$2016-17$} \\
\hline & Maximum & Minimum & Mean & Maximum & Minimum & Mean \\
\hline $\mathrm{pH}$ & 6.6 & 5.3 & 6.1 & 6.7 & 5.4 & 6.1 \\
\hline Organic C (\%) & 0.74 & 0.54 & 0.66 & 0.70 & 0.58 & 0.65 \\
\hline Available N (kg/ha) & 270 & 212 & 244 & 270 & 228 & 252 \\
\hline Available P (kg/ha) & 20.6 & 7.2 & 13.0 & 17.8 & 12.4 & 14.4 \\
\hline Available K (kg/ha) & 220 & 100 & 134 & 180 & 115 & 138 \\
\hline
\end{tabular}


On-farm Evaluation of Balanced Fertilization in Rice-groundnut Cropping System for Productivity, Nutrient Use Efficiency...

yield of groundnut $(2.44 \mathrm{t} / \mathrm{ha})$ were obtained with balanced fertilisation of NPK to both the crops along with $\mathrm{ZnSO}_{4}$ to rice and $\mathrm{CaSO}_{4}$ to groundnut, respectively. This treatment $\left(\mathrm{NPK}+\mathrm{ZnSO}_{4}\right)$ produced 90, 41 19, 21, 4 and $11 \%$ higher yield over the control, N, NP, NK, NPK and FP, respectively in rice and the treatment $\mathrm{NPK}+\mathrm{CaSO}_{4}$ in groundnut increased the pod yield to the tune of $94,59,15,30,5$ and $16 \%$ over control, N, NP, NK, NPK and FP, respectively.

The rice-groundnut system productivity was evaluated in terms of rice equivalent yield (REY). Application of recommended quantity of N, NP, NK and NPK to both rice and groundnut in sequence increased the system REY by $29,64,54$ and $83 \%$ over control, respectively. However, the highest system REY (12.63 t/ha) was recorded by application of recommended quantity of NPK with $\mathrm{ZnSO}_{4}$ to rice and $\mathrm{CaSO}_{4}$ to groundnut and the increases were 89, 47, 15, 24, 4 and $14 \%$ over the control, N, NP, NK, NPK and FP, respectively. The better yield performance under balanced application of NPK may be attributed to existence of synergistic interaction among these macronutrients. Phosphorus is involved in essential metabolic processes of plants including respiration and photosynthesis, helps in better root development, nitrogen fixation along with efficient use of $\mathrm{N}$ by plants. Potassium increases root growth, improves translocation of nutrients and is involved in $\mathrm{N}$ metabolism. The combined application of $\mathrm{N}$ and $\mathrm{P}$ increased the sorghum yield up to $85 \mathrm{bu} / \mathrm{ac}$ ( $1 \mathrm{bushel} / \mathrm{ac}=62.77 \mathrm{~kg} / \mathrm{ha}$ ), while $\mathrm{N}$ alone recorded a yield of $66 \mathrm{bu} / \mathrm{ac}$ (Schlegel and Bond 2020). Similarly, combined application of both P and
$\mathrm{K}$ together enhanced the yield of cornto64 bu/ac as compared to 38-41 bu/ac with $\mathrm{P}$ alone (Usherwood and Segars 2001). Ravisankar et al. (2014), Hiremath et al. (2016) and Panwar et al. (2019) have also reported better yield performance under balanced NPK fertilization than application of $\mathrm{N}$ alone.

Four prediction equations have been developed for rice grain, straw; groundnut pod and haulm yield (Table 3). Adj. $R^{2}$ values indicate that the models are best fit to the equations.

\section{Partial factor productivity (PFP)}

Application of balanced fertilizer improved the partial factor productivity (PFP) of applied $\mathrm{N}$ compared to application of $\mathrm{N}$ alone or NP and NK in both the crops and of the system (Table 4). Combined application of NP increased the PFPn by 19,34 and $27 \%$ in rice, groundnut and rice-groundnut system, respectively, compared to that under sole $\mathrm{N}$ application. Similarly, combined application of NK increased the PFPn by 19,21 and $20 \%$ in rice, groundnut and ricegroundnut system, respectively, over that under sole $\mathrm{N}$ application. However, the maximum increment in PFPn to the tune of 36,46 and $42 \%$ in rice, groundnut and ricegroundnut system, respectively, were observed under balanced fertilization of NPK over sole N application. Similar to $\mathrm{N}$, the improvement for PFP of $\mathrm{P}$ when combined with NK over application with $\mathrm{N}$ alone were 14,10 and $11 \%$ in rice, groundnut and rice-groundnut system, respectively and the improvement for PFP of $\mathrm{K}$ when combined with NP over

Table 2: Productivity and economics of rice-groundnut system as influenced by nutrient application (mean of two years).

\begin{tabular}{|c|c|c|c|c|c|c|c|c|}
\hline \multirow{3}{*}{ Treatment } & \multicolumn{5}{|c|}{ Productivity (t/ha) } & \multicolumn{3}{|c|}{ Economics ( $\times 10^{3}$ ₹/ha) } \\
\hline & \multicolumn{2}{|c|}{ Rice } & \multicolumn{2}{|c|}{ Groundnut } & \multirow{2}{*}{$\begin{array}{c}\text { System } \\
\text { REY }\end{array}$} & \multirow{2}{*}{$\begin{array}{l}\text { Cost of } \\
\text { cultivation }\end{array}$} & \multirow{2}{*}{$\begin{array}{l}\text { Net } \\
\text { return }\end{array}$} & \multirow{2}{*}{$\begin{array}{l}\text { Cost: benefit } \\
\text { ratio }\end{array}$} \\
\hline & Grain & Straw & Pod & $\overline{\text { Haulm }}$ & & & & \\
\hline Control & 2.66 & 3.75 & 1.26 & 2.19 & 6.67 & 83.98 & 15.97 & 1.19 \\
\hline $\mathrm{N}$ & 3.58 & 4.82 & 1.53 & 2.62 & 8.60 & 85.23 & 43.50 & 1.51 \\
\hline NP & 4.25 & 5.53 & 2.12 & 3.35 & 10.94 & 89.01 & 74.24 & 1.83 \\
\hline NK & 4.19 & 5.41 & 1.87 & 3.13 & 10.27 & 87.47 & 65.98 & 1.75 \\
\hline NPK & 4.85 & 5.77 & 2.32 & 3.53 & 12.18 & 91.34 & 89.95 & 1.99 \\
\hline $\mathrm{NPK}+\mathrm{ZnSO}_{4} / \mathrm{CaSO}_{4}$ & 5.06 & 5.88 & 2.44 & 3.55 & 12.63 & 95.24 & 92.69 & 1.97 \\
\hline Farmers' practice & 4.54 & 5.63 & 2.10 & 3.35 & 11.07 & 89.58 & 75.68 & 1.84 \\
\hline $\operatorname{SEm}( \pm)$ & 0.05 & 0.07 & 0.04 & 0.05 & 0.11 & & 1.68 & \\
\hline$C D(P=0.05)$ & 0.14 & 0.19 & 0.10 & 0.13 & 0.32 & & 4.75 & \\
\hline
\end{tabular}

REY, rice equivalent yield; Recommended dose of nutrients (N-P-K kg/ha): rice, 80-17.5-33; groundnut, 20-17.5-33; Farmers' practice (N-P-K kg/ha): rice, 61-13.3-26; groundnut, 14-14.9-24.8* $\mathrm{ZnSO}_{4} @ 25 \mathrm{~kg} / \mathrm{ha}$ to rice and $\mathrm{CaSO}_{4} @ 250 \mathrm{~kg} / \mathrm{ha}$ to groundnut.

Sale price $(₹ / t)$ : paddy grain, 14,100 in $2015-16$ and 14,700 in 2016-17; paddy straw, 1,000; groundnut pod, 50,000 in 2015-16 and 46,000 in 2016-17.

Table 3: Prediction equation of grain and straw yield (mean of two years).

\begin{tabular}{llcc}
\hline Particulars & Prediction equation & Adj R & $\begin{array}{c}\text { Significance of } \\
\text { the model }\end{array}$ \\
\hline Rice grain & $2.69+0.010824 \mathrm{~N}+0.40787 \mathrm{P}+0.01992 \mathrm{~K}$ & 0.98 & 0.01217 \\
Rice straw & $3.79+0.013509 \mathrm{~N}+0.034352 \mathrm{P}+0.014728 \mathrm{~K}$ & 0.93 & 0.03947 \\
Groundnut pod & $1.26+0.01559 \mathrm{~N}+0.029377 \mathrm{P}+0.008038 \mathrm{~K}$ & 0.98 & 0.00953 \\
Groundnut haulm & $2.20+0.024545 \mathrm{~N}+0.03336 \mathrm{P}+0.010911 \mathrm{~K}$ & 0.94 & 0.03288 \\
\hline
\end{tabular}


application with $\mathrm{N}$ alone were 16,21 and $19 \%$ in rice, groundnut and rice-groundnut system, respectively.

\section{Agronomic efficiency of nutrients}

Agronomic efficiency (AE) of applied nutrients can be increased in rice, groundnut and rice-groundnut system by combined application of recommended quantity of $\mathrm{N}, \mathrm{P}$ and $\mathrm{K}$ rather than sole application N or NP and NK (Table 5). Combined application of NP increased the AE of $\mathrm{N}$ by 73 , 169 and $122 \%$ in rice, groundnut and rice-groundnut system, respectively instead of $\mathrm{N}$ alone and the $\mathrm{AEn}$ further increased to 139,233 and $186 \%$ in rice, groundnut and rice-groundnut system, respectively, by applying recommended quantity of $\mathrm{N}$ with $\mathrm{P}$ and $\mathrm{K}$ rather than $\mathrm{N}$ alone. Similar to $\mathrm{N}$, the improvements for $A E$ of $P$ when combined with NK over application with $\mathrm{N}$ alone were 38,24 and $29 \%$ in rice, groundnut and rice-groundnut system, respectively and the improvements for AE of $\mathrm{K}$ when combined with NP over application with $\mathrm{N}$ alone were 43,61 and $53 \%$ in rice, groundnut and rice-groundnut system, respectively. Ravisankar et al. (2014) and Panwar et al. (2019) have also reported higher agronomic efficiency of applied nutrients in cereal based cropping systems under combined application over their lone application.

\section{Uptake of nutrients}

Application of balanced fertilizer along-with $\mathrm{ZnSO}_{4} / \mathrm{CaSO}_{4}$ i.e. $\mathrm{NPK}+\mathrm{ZnSO}_{4}$ to rice and $\mathrm{NPK}+\mathrm{CaSO}_{4}$ to groundnut recorded higher uptake of $\mathrm{N}, \mathrm{P}$ and $\mathrm{K}$ by rice-groundnut system (Table 6 ). The increases in $N$ uptakes due to application of recommended $\mathrm{NPK}+\mathrm{ZnSO}_{4}$ to rice and NPK $+\mathrm{CaSO}_{4}$ to groundnut were found to be $89,44,15,22,3$ and $14 \%$ over control, N, NP, NK, NPK and farmers' practice respectively, while the respective increases for $P$ uptakes were $88,47,12,21,3$ and $12 \%$ and $\mathrm{K}$ uptakes were 82,45 , $18,14,2$ and $14 \%$. The uptake of $\mathrm{N}$ when applied alongwith $P(213.7 \mathrm{~kg} / \mathrm{ha})$ and uptake of $\mathrm{N}$ when applied alongwith $\mathrm{K}(201.6 \mathrm{~kg} / \mathrm{ha})$ were higher by 25 and $18 \%$ respectively, over that under application of $\mathrm{N}$ alone. Similarly, the respective increases for $P$ uptakes were 31 and $22 \%$ and respective increases for $\mathrm{K}$ uptakes were 23 and $28 \%$. However, both the treatments ( $\mathrm{N}$ with $\mathrm{P}$ or $\mathrm{N}$ with $\mathrm{K}$ ) recorded lower N, P and K uptake compared to balanced fertilisation with NPK. Patra et al. (2019) also reported higher uptake of nutrients under balanced fertilization in cereal based cropping system.

\section{Economics of rice-groundnut system}

Balanced application of $\mathrm{NPK}+\mathrm{ZnSO}_{4}$ to rice and $\mathrm{NPK}+\mathrm{CaSO}_{4}$ to succeeding groundnut fetched maximum system net return (₹92,690/ha) followed by application of recommended NPK to both the crops (₹89,950/ha) (Table 2). This treatment also increased the system net return by 480 , $113,25,40,3$ and $22 \%$ over control, N, NP, NK, NPK and $\mathrm{FP}$, respectively, while the increases in respective cost of cultivation were only $13,12,7,9,4$ and $6 \%$. The increases in net return under application of $\mathrm{N}$ with $\mathrm{P}$ or $\mathrm{N}$ with $\mathrm{K}$ over $\mathrm{N}$ alone were 71 and $52 \%$, respectively. However, both the treatments ( $\mathrm{N}$ with $\mathrm{P}$ or $\mathrm{N}$ with $\mathrm{K}$ ) recorded lower marginal returns compared to balanced fertilisation with NPK. Singh et al. (2017) also reported higher net return with balanced

Table 4: Partial factor productivity (PFP) of N, P and $\mathrm{K}$ in ricegroundnut system as influenced by nutrient application (mean of 2 years).

\begin{tabular}{cccc}
\hline & Rice & Groundnut & Rice-groundnut \\
Treatment & (kg grain/ & (kg pod/ & (kg REY/ \\
& kg nutrient) & kg nutrient) & kg nutrient) \\
\hline
\end{tabular}

\begin{tabular}{lccc}
\hline PFP (N) & & & \\
N alone & 44.71 & 75.27 & 85.96 \\
With P & 53.08 & 100.60 & 109.39 \\
With K & 52.34 & 91.29 & 102.73 \\
With PK & 60.60 & 110.16 & 121.77 \\
PFP (P) & & & \\
With N & 242.64 & 114.98 & 312.53 \\
With NK & 277.05 & 125.89 & 347.92 \\
PFP (K) & & & \\
With N & 126.88 & 55.33 & 155.65 \\
With NP & 146.92 & 66.76 & 184.50 \\
\hline
\end{tabular}

Table 5: Agronomic efficiency ( $\mathrm{AE}$ ) of $\mathrm{N}, \mathrm{P}$ and $\mathrm{K}$ in rice-groundnut system as influenced by nutrient application (mean of 2 years).

\begin{tabular}{lccc}
\hline & Rice & Groundnut & Rice-groundnut \\
Treatment & (kg grain/ & (kg pod/ & (kg REY/ \\
& nutrient) & kg nutrient) & kg nutrient) \\
\hline
\end{tabular}

\section{$\mathrm{AE}(\mathrm{N})$}

$\mathrm{N}$ alone

11.4

19.21

With $\mathrm{P}$

19.80

14.98

42.64

With $\mathrm{K}$

19.07

40.31

35.98

With PK

27.33

31.00

55.02

AE (P)

With $\mathrm{N}$

90.54

49.86

121.82

With NK

124.94

46.07

157.21

$A E(K)$

With $\mathrm{N}$

46.22

18.79

54.52

With NP

66.26

30.22

83.37

Table 6: Nutrient uptake in rice-groundnut system as influenced by nutrient application (mean of 2 years data).

\begin{tabular}{lccr}
\hline Treatment & $\begin{array}{c}\text { Nitrogen } \\
(\mathrm{kg} / \mathrm{ha})\end{array}$ & $\begin{array}{r}\text { Phosphorus } \\
(\mathrm{kg} / \mathrm{ha})\end{array}$ & $\begin{array}{r}\text { Potassium } \\
(\mathrm{kg} / \mathrm{ha})\end{array}$ \\
\hline Control & 130.4 & 19.0 & 96.1 \\
$\mathrm{~N}$ & 170.5 & 24.3 & 120.6 \\
$\mathrm{NP}$ & 213.7 & 31.9 & 148.0 \\
$\mathrm{NK}$ & 201.6 & 29.6 & 154.1 \\
$\mathrm{NPK}$ & 237.6 & 34.8 & 171.9 \\
$\mathrm{NPK}+\mathrm{ZnSO}_{4} / \mathrm{CaSO}_{4}$ & 245.8 & 35.7 & 175.2 \\
Farmers' practice & 215.5 & 31.8 & 153.8 \\
SEm $( \pm)$ & 2.25 & 0.35 & 1.59 \\
CD $(\mathrm{P}=0.05)$ & 6.35 & 0.99 & 4.48 \\
\hline
\end{tabular}


On-farm Evaluation of Balanced Fertilization in Rice-groundnut Cropping System for Productivity, Nutrient Use Efficiency...

fertilization in cereal-based cropping system. The benefit: cost ratio was higher under recommended application of NPK.

\section{CONCLUSION}

In conclusion, our study shows that balanced fertilization with recommended doses of nitrogen, phosphorus and potassium to both rice and groundnut along with $\mathrm{ZnSO}_{4}$ to rice and $\mathrm{CaSO}_{4}$ to the succeeding groundnut is required for achieving higher system equivalent yield, increased efficiency of native and applied nutrients and better net returns with better residual soil fertility to ricegroundnut system in Mid Central Table Land Zone of Odisha.

Conflict of interest: None.

\section{REFERENCES}

Casman, K.G., Gines, G.C., Dizon, M.A., Samson, M.I., Al-cantara, J.M. (1996). Nitrogen-use efficiency in tropical low land rice systems: Contributions from indigenous and applied nitrogen. Field Crops Research. 47: 1-2.

Govt. of Odisha. (2015). Odisha Agriculture Statistics 2013-14. Directorate of Agriculture and Food Production, Government of Odisha, Bhubaneswar.

Hiremath, S.M., Mohan Kumar, R. and Gaddi A Kumar. (2016). Influence of balanced nutrition on productivity, economics and nutrient uptake of hybrid maize (Zea mays)-chickpea (Cicer arietinum) cropping sequence under irrigated ecosystem. Indian Journal of Agronomy. 61(3): 292-96.

Jackson, M.L. (1973). Soil Chemical Analysis. Prentice Hall of India Pvt. Ltd, New Delhi. pp. 183-204.
Panwar, A.S., Shamim, M., Babu, S., Ravishankar, N., Prusty, A.K., Alam, N.M., Singh, D.K., Bindhu, J.S., Kaur, J., Dashora, L.N., Latheef Pasa, M.D., Chaterjee, S., Sanjay, M.T. and Desai, I.J. (2019). Enhancement in productivity, nutrient use efficiency and economics of rice-wheat cropping systems in India through farmer's participatory approach. Sustainability. 11: 122.

Patra, A.K., Garnayak, L.M., Mishra, K.N., Mohanty, T.R., Mohapatra, B.K. and Swain, S.K.(2019). Balanced fertilization in rice (Oryza sativa L.)-groundnut [Arachis hypogaea] cropping system. Indian Journal of Agronomy. 64(3): 52-56.

Rajendra Prasad. (2009). Efficient fertilizer use: The key to food security and better environment. Journal of Tropical Agriculture. 47(1-2): 1-17.

Ravisankar, N., Gangwar, B. and Prasad, K. (2014). Influence of balanced fertilization on productivity and nutrient use fficiency of cereal based cropping systems. Indian Journal of Agricultural Sciences. 84(2): 248-54.

Schlegel, A. and Bond, H.D. (2020). Long-term nitrogen and phosphorus fertilization of irrigated grain sorghum. Kansas Agricultural Experiment Station Res Rep. 6: 1-6.

Singh, D.K., Singh, G.D., Singh, R., Singh, A.P., Chaturvedi, S. and Singh, M. (2017). Himalayas farmer participatory evaluation of balanced application of nutrients in rice (Oryza sativa)- wheat (Triticum aestivum) system in Kumaon hills. Indian Journal of Agronomy. 62(4): 401-06.

Singh, V.K., Tiwari, R., Gill, M.S., Sharma, S.K., Tiwari, K.N., Dwivedi, B.S., Shukla, A.K., Mishra, P.P. (2008). Economic viability of site-specific nutrient management in rice-wheat cropping. Better Crops India. 2:16-19.

Usherwood, N.R. and Seagars, W.I.. (2001). Nitrogen interactions with phosphorus and potassium for optimum crop yield, nitrogen use effectiveness and environmental stewardship. Science World. 1: 57-60. 